\title{
Estimating cation exchange capacity and clay content from agricultural soil testing data
}

\author{
Mari Räty ${ }^{1}$, Riikka Keskinen ${ }^{2}$, Markku Yli-Halla ${ }^{3}$, Juha Hyvönen ${ }^{4}$ and Helena Soinne ${ }^{5}$ \\ ${ }^{1}$ Natural Resources Institute Finland, Halolantie 31 A, FI-71750 Maaninka, Finland \\ ${ }^{2}$ Natural Resources Institute Finland, Tietotie 4, Fl-31600 Jokioinen, Finland \\ ${ }^{3}$ Department of Agricultural Sciences, Viikinkaari 9, Fl-00014 University of Helsinki, Finland \\ ${ }^{4}$ Natural Resources Institute Finland, Ounasjoentie 6, FI-96200 Rovaniemi, Finland \\ ${ }^{5}$ Natural Resources Institute Finland, Latokartanonkaari 9, FI-00790 Helsinki, Finland \\ e-mail: mari.raty@luke.fi
}

\begin{abstract}
Clay content and the ability to reversibly retain cations affect many essential chemical and physical properties of soil, such as pH buffering and carbon sequestration. Cation exchange capacity (CEC) and base saturation are also commonly used as criteria in soil classification. However, determination of CEC and particle-size distribution is laborious and not included in routine soil testing. In this study, pedotransfer functions including soil test cations (STCat; $\left.\mathrm{Ca}^{2+}+\mathrm{Mg}^{2+}+\mathrm{K}^{+}\right)$, $\mathrm{pH}$ and soil organic carbon (SOC, \%) as explanatory variables were developed for estimating CEC, titratable acidity $\left(\mathrm{TA} \mathrm{H}^{+}+\mathrm{Al}^{3+}\right)$ and clay content (clay, \%). In addition, reference values for potential $\mathrm{CEC}$ and its components were determined for Finnish mineral and organic soils. The mean of potential CEC extracted by $1 \mathrm{M}$ ammonium acetate at $\mathrm{pH} 7.0$ ranged from 14 (range 6.4-25) in coarse soils to $33(21-45) \mathrm{cmol}(+) \mathrm{kg}^{-1}$ in heavy clay soils, and from $42(24-82)$ in mull soils to $77(25-138) \mathrm{cmol}(+) \mathrm{kg}^{-1}$ in peat soils. The average CEC of clay and SOC were 27 and $160 \mathrm{cmol}(+) \mathrm{kg}^{-1}$, respectively. Titratable acidity occupied $53 \%$ and around $40 \%$ of the CEC sites in organic and mineral soils, respectively, evidencing that it is a prominent component of the potential CEC in these predominantly acidic soils. STCat, $\mathrm{pH}$ and SOC explained $96 \%$ of the variation in potential CEC. STCat and pH can be used in estimating the clay content especially for soils containing over $30 \%$ clay. In coarse textured soils, in contrast, SOC hampers the STCat based estimation of clay content.
\end{abstract}

Key words: exchangeable cations, boreal environment, organic carbon, pedotransfer function, titratable acidity

\section{Introduction}

Cation exchange capacity (CEC) is one of the basic properties commonly reported when characterizing soil in a scientific context. Reflecting the negative charges on soil particles, CEC indicates the ability of a soil to reversibly retain cations by electrostatic forces (e.g. Bache 1976, Ross and Ketterings 1995). This phenomenon is linked to soil nutrient stock and supply, mobility of elements and $\mathrm{pH}$ buffering, all of which are important factors in agricultural land use. However, the available methods of CEC analysis are too laborious for CEC determination to be included in routine soil testing protocols (Sumner and Miller 1996, Ciesielski et al. 1997).

Predicting the CEC value from more readily available soil data via pedotransfer functions is a credible alternative for direct laboratory measurement (McBratney et al. 2002). Permanent charge of layer silicates originating from isomorphous substitution within the mineral structure and variable $\mathrm{pH}$-dependent charge generated by dissociation of hydroxyl and carboxyl groups are the main components contributing to CEC (Bache 1976). Consequently, clay and organic matter contents explain the majority of variability in the CEC values in many studies (e.g. Bell and van Keulen 1995, Parfitt et al. 1995, Krogh et al. 2000, Fooladmand 2008, Sulieman et al. 2018, Mishra et al. 2019). However, due to spatial variation in clay mineralogy and composition of organic matter, different pedotransfer functions are needed in different regions (Seybold et al. 2005).

Estimating potential CEC on the basis of soil test results obtained with the acid (pH 4.65) ammonium acetate solution, which is used in soil testing in Finland (Vuorinen and Mäkitie 1955), is not entirely straightforward. Exchangeable $\mathrm{Ca}, \mathrm{Mg}, \mathrm{K}$ and $\mathrm{Na}$ are extracted from soil roughly equally with the acid and neutral ammonium acetate of the same molarity (Niskanen and Jaakkola 1986), but the challenges are mostly related to the amount of the variable charge associated with soil organic and mineral matter (Curtin et al. 1996). Part of these sites are available for and occupied by exchangeable cations, but in acid soils many of the sites are blocked by non-dissociated protons. Those sites are not available for cation exchange at soil pH but become accessible at pH 7.0 or at whatever higher $\mathrm{pH}$ CEC is determined, and should thus be included in the value of potential CEC. Niskanen and Jaakkola (1986) 
estimated effective CEC on the basis of the acid ammonium acetate soil test, and in their material of 430 soil samples (average $\mathrm{pH}$ 5.8), exchangeable acidity occupied only $6 \%$ of the effective CEC. Therefore, accurate estimates for the effective CEC were obtained. However, potential CEC is a more relevant characteristic, for example, in soil classification and in the determination of liming requirements. When attempting to estimate the potential $\mathrm{CEC}$ at $\mathrm{pH} 7.0$, the component of non-dissociated variable charge sites, operationally determined as titratable acidity $\left(T A ; \mathrm{H}^{+}+\mathrm{Al}^{3+}\right)$, is much higher in acid soils, as compared to the exchangeable acidity.

Soil texture is rarely measured in routine soil analyses aimed to adjust fertilization. However, clay and fine-sized particle (FINES; $\varnothing<0.02 \mathrm{~mm}$ ) content plays a significant role in soil fertility and in estimating soil carbon (C) sequestration potential (Hassink 1996, Wiesmeier et al. 2019). Further, recent studies have shown that soil clay to $C$ ratio plays a key role in determining soil structural stability and yield potential (Soinne et al. 2016, Soinne et al. 2021). There is often a close correlation between CEC and clay, encouraging an attempt to predict the soil clay content on the basis of CEC or its components. A low-cost estimate of clay content based on agricultural soil test data would enable more accurate determination of liming requirement, better targeting of soil improvement measures based on soil clay/C ratio and better estimation of soil $\mathrm{C}$ sequestration potential.

In this study, a data set of CEC values, measured at $\mathrm{pH} 7.0$ and representing various mineral and organic soils of Finland, was compiled by collecting previously published and unpublished results from soil surveys and field studies. Supplementary analyses of archived samples were carried out to fill major gaps in the existing material. The acquired data was used to 1) calculate reference values for the CEC and its components in different soil types, 2) develop pedotransfer functions for predicting the CEC and its components from soil organic C (SOC) and clay contents, $\mathrm{pH}$, and $\mathrm{Ca}^{2+}, \mathrm{Mg}^{2+}$, and $\mathrm{K}^{+}$extracted in standard agronomic soil testing, and 3) develop pedotransfer functions for soil clay and FINES content using the above-mentioned characteristics as explanatory variables. The results benefit full exploitation of the soil testing data and practical interpretation of the CEC values at farm level.

\section{Material and methods}

\section{Study area}

In Finland, agricultural land (2.3 million ha) constitutes about 7.5\% of the total land area. Medium- and coarsetextured mineral soils and clay soils make up about $22 \%, 36 \%$ and $28 \%$ of the agricultural area of Finland, respectively. Organic soils account for about $13 \%$ of the arable area (Lemola et al. 2018, Luke 2020). Typically, the fine clay fraction $(<0.0002 \mathrm{~mm}$ ) mostly consists of illite, chlorite, vermiculite and amorphous material, whereas coarse clay $(0.0002-0.002 \mathrm{~mm}$ ) and coarser fractions are increasingly composed of feldspars and quartz (Sippola 1974). The formation of geologically young Finnish soils has been influenced by the Weichselian glaciation, which ended about 11500 years ago, and consequently, the soils of Finland are rather young and mostly relatively weakly developed. These soils are inherently acidic (Reuter et al. 2008) and rich in organic C at the European scale (Aksoy et al. 2016). Cryic temperature regime of Soil Taxonomy prevails in Finland (Yli-Halla and Mokma 1998), and commonly the clayey soils have an aquic moisture regime (Yli-Halla and Mokma 2001). According to the World Reference Base for Soil Resources (IUSS Working Group WRB 2015), clay soils of Finland are typically classified as Vertic Endogleyic Luvic Stagnosols or Luvic Gleysols, and fine silt soils as Stagnic Regosols. Coarse silt and fine sand soils with deeper layers rich in clay are commonly classified as Endogleyic Luvic Planosols, whereas Endogleyic Cambisols are common in deeper medium-textured soils and (Gleyic) Podzols in coarse-textured soils (Yli-Halla and Nyborg 2013). Cultivated organic soils are usually classified as Umbric or Histic Gleysols or Sapric Histosols (Yli-Halla and Peltovuori 2009).

\section{Soil samples and analysis}

This study was based on Finnish soil samples collected from the plough layer of cultivated soils, and a few virgin soils. Owing to the deficient description of land uses in the original paper of Marttila (1965), the distribution of the samples into cultivated and virgin soils is slightly unclear. This group of 45 samples consists of 31-33 cultivated and 14-12 virgin soils. Values of potential CEC determined at $\mathrm{pH} 7.0$ were collected, together with other relevant data, from all published sources known and available for participating researchers and personal archives containing unpublished data from previous and ongoing projects of the participating researchers (Table 1). The retrieved data set was complemented with the determination of CEC in a few additional soils to overcome methodological incompatibilities and increase the number of organic soil samples. The CEC analysis was carried out by using neutral ammonium acetate $\left(1 \mathrm{M} \mathrm{CH}_{3} \mathrm{COONH}_{4}, \mathrm{pH}\right.$ 7.0) extraction in soil/solution ratio of 1:5 (w/v). The sample 
suspensions were agitated for $1 \mathrm{~h}$ and then allowed to stand overnight, after which the agitation was continued for $10 \mathrm{~min}$. Thereafter, the suspensions were centrifuged, and the supernatants filtered. The extraction was repeated in 15 min length for 3 times combining all the supernatants. From the final solution, concentrations of $\mathrm{Ca}, \mathrm{Mg}, \mathrm{K}$ and $\mathrm{Na}$ were analyzed by ICP-OES. The TA was determined by back-titration to $\mathrm{pH}$ 7.0. The CEC value was calculated as the sum of the extracted cations and TA in $\mathrm{cmol}(+) \mathrm{kg}^{-1}$.

Particle-size distribution was determined by a pipette method (Elonen 1971). In the older data sets (Marttila 1965, Mäkitie and Virri 1965, Sillanpää 1982), SOC was determined with the Walkley - Black method while in the other data sets, including the new measurements for this study, total $\mathrm{C}$ was determined using dry combustion (Dumas method). In the acid soils of Finland, this total C can be taken to represent SOC (Nelson and Sommers 1996). Soil $\mathrm{pH}$ was measured in a soil-water suspension (1:2.5 v/v). The same procedure for the determination of CEC was used in all datasets listed in Table 1, except in Marttila (1965), where the samples were leached with $1 \mathrm{M}$ $\mathrm{CH}_{3} \mathrm{COONH}_{4}, \mathrm{pH} 7.0$, in a percolation tube.

Table 1. Data sets with number of soil samples ( $\mathrm{n}$ ) used in this study for the modelling (calibration/validation) of cation exchange capacity (CEC) and titratable acidity (TA)

\begin{tabular}{|c|c|c|c|}
\hline Data set & $\mathrm{n}$ & Remarks & Calibration/Validation \\
\hline Sillanpää 1982 & 21 & $\begin{array}{l}\text { A set of archived samples from cultivated soils in Finland } \\
\text { reanalyzed due to a different method originally used }\end{array}$ & Calibration \\
\hline Yli-Halla et al. 2000 & 24 & $\begin{array}{l}\text { Plough layer samples of pedons collected for soil } \\
\text { classification of cultivated soils in southern and central } \\
\text { Finland }\end{array}$ & Calibration \\
\hline Soinne et al. 2021 & 21 & $\begin{array}{l}\text { Cultivated mineral soils from southwestern and east- } \\
\text { central Finland (Oranki project) }\end{array}$ & Calibration \\
\hline Unpublished & 22 & $\begin{array}{l}\text { Archived plough layer results from cultivated experimental } \\
\text { soils and pedons collected for soil classification purposes } \\
\text { from various parts of Finland }\end{array}$ & Calibration \\
\hline Unpublished & 14 & $\begin{array}{l}\text { Results of plough layer samples from central Finland used } \\
\text { in compiling Finnish soil database }\end{array}$ & Calibration \\
\hline Palojärvi et al. 2002 & 10 & $\begin{array}{l}\text { Plough layer samples from conventionally and organically } \\
\text { cultivated fields in southern Finland (MABIN project) }\end{array}$ & Calibration \\
\hline Mäkitie and Virri 1965 & 10 & $\begin{array}{l}\text { Clayey plough layer samples from mid-Uusimaa, southern } \\
\text { Finland }\end{array}$ & Calibration \\
\hline Hyväluoma et al. 2020 & 2 & $\begin{array}{l}\text { Plough layer samples of organic soils from Ostrobothnia, } \\
\text { western Finland }\end{array}$ & Calibration \\
\hline Peltovuori et al. 2002 & 3 & $\begin{array}{l}\text { Plough layer samples of clayey and coarse textured soils } \\
\text { from southern and western Finland }\end{array}$ & Calibration \\
\hline Paasonen-Kivekäs and Yli-Halla 2005 & 2 & $\begin{array}{l}\text { Plough layer samples of fine sand soils from Ostrobothnia, } \\
\text { western Finland }\end{array}$ & Calibration \\
\hline Keskinen et al. 2016 & 41 & $\begin{array}{l}\text { Monitoring of cultivated soils covering the agricultural } \\
\text { area in Finland; new analyses of archived samples of } \\
\text { organic soils from the } 2018 \text { sampling campaign }\end{array}$ & $\begin{array}{l}\text { Calibration: } 33 \text { soils } \\
\text { Validation: } 8 \text { randomly } \\
\text { selected organic soils }\end{array}$ \\
\hline Marttila 1965 & 45 & Cultivated and virgin soils from various parts of Finland & Validation \\
\hline Mattila and Rajala 2020 & 16 & $\begin{array}{l}\text { Cultivated soils from Finland sampled in } 2019 \text { representing } \\
\text { productive (K) and unproductive (0) fields }\end{array}$ & $\begin{array}{l}\text { Validation. Not included } \\
\text { in descriptive statistics } \\
\text { (exchangeable cations } \\
\text { and texture not reported) }\end{array}$ \\
\hline
\end{tabular}

The final data comprising 215 soil samples (data set of Mattila and Rajala [2020] not included) was classified in soil types according to the Finnish system (Aaltonen et al. 1949) where soils are grouped into mineral and organic soils on the basis of the soil organic matter (SOM) content (Table 2). SOC content was converted to SOM content using the van Bemmelen factor of 1.724, which is found to be appropriate for Finnish cultivated mineral soils (Heikkinen et al. 2021). For descriptive statistics, the mineral soils were further classified to heavy clays, clays, mediumtextured soils (mostly different loam soils) and coarse soils (mostly loamy sands) based on their clay $(<0.002 \mathrm{~mm}$ ) content only, because the complete particle-size distribution had not been presented for every dataset. Organic soils were further divided to mull soils and peat soils according to their SOM content (see Table 2). For 71 of the samples, information on $\mathrm{Ca}, \mathrm{Mg}$ and $\mathrm{K}$ acquired by the soil testing procedure used in Finland (AAAc; a single acid ammonium acetate-extraction, $\left.0.5 \mathrm{M} \mathrm{CH}_{3} \mathrm{COONH}_{4}-0.5 \mathrm{M} \mathrm{CH}_{3} \mathrm{COOH}, \mathrm{pH} 4.65\right)$ in soil/solution ratio of 1:10 (v/v) and shaking time of $1 \mathrm{~h}$, Vuorinen and Mäkitie 1955) was available. 
Table 2. Soil classification used in the study based on the soil organic matter (SOM) and clay $(<0.002 \mathrm{~mm}$ ) contents

\begin{tabular}{lllll}
\hline Soil type & & SOM (\%) & Clay (\%) & $\mathrm{n}$ \\
\hline Organic soils & Peat & $\geq 40$ & & 37 \\
& Mull & $20-39.9$ & & 30 \\
Mineral soils & Heavy clay & & $>60$ & 22 \\
& Clay & & $30-59.9$ & 48 \\
& Medium & $<20$ & $12-29.9$ & 41 \\
& Coarse & & $<12$ & 37 \\
\hline
\end{tabular}

For the soil test analysis in Finland, an equal volume of soils is taken for the analysis, whereas the CEC measurement is done on soil mass basis. For the regression models, STCat results $\left(\mathrm{mg} \mathrm{l}^{-1}\right)$ were transformed to $\mathrm{cmol} \mathrm{I}^{-1}$ taking into account the charge of each cation (i.e. STCat cmol $(+) \mathrm{I}^{-1}=\mathrm{STCa} \mathrm{cmol} \mathrm{I}^{-1} \times 2+\mathrm{STMg} \mathrm{cmol} \mathrm{I}^{-1} \times 2+\mathrm{STK}_{\mathrm{cmol} \mathrm{I}}^{-1}$ ). In predicting the $\mathrm{CEC}$, the sum of cation charges was used whereas in predicting the clay content, each cation was included separately (i.e. STCa $\mathrm{cmol} \mathrm{I}^{-1}$, STMg cmol I-1 and STK $\mathrm{cmol} \mathrm{I}^{-1}$, charges not taken into account) in the regression model.

An additional data set consisting of 571 soil samples mainly from the national soil monitoring of Finland (Keskinen et al. 2016) and Oranki-project (Soinne et al. 2021) was compiled for predicting the soil clay content and the fine particles content (FINES; $\varnothing<0.02 \mathrm{~mm}$ ) on the basis of $\mathrm{pH}, \mathrm{C}$ and STCat. The validation data used for clay and FINES content models was collected from on-going projects and included 31 samples from different fields in southern Finland.

\section{Data analysis}

Pedotransfer functions were constructed using linear regression analysis for the calibration data to estimate CEC, TA, Clay\% and FINES\% from various soil properties ( $\mathrm{pH}$, STCat, SOC and Clay). Regression models were fitted separately for all soils, mineral soils and organic soils in modelling of CEC and TA, and separately for all soils, clay soils (clay\% > 30) and coarse soils (clay\% < 30) in modelling of Clay\% and FINES\%. The square root transformation was applied for TA and STMg to meet model assumptions (normally distributed errors with constant variance). In some models, 1-2 observations were excluded as outliers based on their studentized residual values $(>3$ or $<-3$ ). In all models, only predictors significant at the 0.05 level were included. Different models for the same predicted variable were compared by two statistics based on the model specific data: coefficient of determination $\left(R^{2}\right)$ was used to assess the model explanatory power and root mean square error (RMSE) to assess the model explanatory error. In addition to their performance ( $\mathrm{R}^{2}$ and RMSE), reported models were selected considering the availability of predictive variables for the potential users of these equations (e.g., SOC is not commonly analyzed in agronomic soil testing in Finland). All models were created using the SAS Enterprise Guide 7.1 (SAS Institute Inc., Cary, NC, USA).

Models with $\mathrm{R}^{2}$ above 0.7 were tested with validation data and the performance of the models was evaluated using the statistics $\mathrm{R}^{2}$ (prediction power), RMSE (error variation) and ME (mean error = bias). RMSE was calculated from the average square difference between the predicted value $\left(y_{\text {pred }}\right)$ and the observed value $y_{\text {obs }}$ (eq. a) and $M E$ as the mean difference between $\mathrm{y}_{\text {pred }}$ and $\mathrm{y}_{\mathrm{obs}}$ (eq. $\mathrm{b}$ ):

a)

$$
R M S E=\sqrt{\frac{1}{N} \sum_{i=1}^{N}\left(y_{\text {pred }}-y_{\text {obs }}\right)^{2}}
$$

b)

$$
M E=\frac{1}{N} \sum_{i=1}^{N}\left(y_{\text {pred }}-y_{\text {obs }}\right)
$$

\section{Results \\ Characteristics of the studied soils}

According to descriptive statistics shown in Table 3, the $\mathrm{pH}\left(\mathrm{H}_{2} \mathrm{O}\right)$ of the study soils ranged within four $\mathrm{pH}$ units from very acidic to neutral $\mathrm{pH}$ values. Almost all soils were acidic, and the median values of the different soil groups ranged between 5.1 and 5.9. The $\mathrm{pH}$ values within the individual soil types overlapped but, in general, organic soils tended to be more acidic than the mineral soils. The $\mathrm{pH}$ in most soils was thus much lower than the $\mathrm{pH} 7.0$ at which the potential CEC is usually measured, suggesting an abundance of TA. Because the main grouping of soils was based on SOM content, the mean SOC content in peat soils (36\%, range $23-53 \%$ ) was over twofold compared 
to mull soils (16\%, range $12-23 \%$ ) (Table 3 ). Within mineral soils, the SOC content ranged between $0.7 \%$ and $11 \%$, and there was strong overlapping between the different textural groups. However, the mean SOC was higher for clay soils (4.3-4.6\%) than for medium-textured or coarse soils $(2.6-3.5 \%)$.

Table 3. General statistics for soil organic carbon (SOC) and pH measured in water in different soil types

\begin{tabular}{|c|c|c|c|c|c|c|c|c|c|}
\hline \multirow{2}{*}{ Soil type } & \multirow{2}{*}{$\mathrm{n}$} & \multirow{2}{*}{ Mean \pm SD } & \multirow{2}{*}{ Min } & \multicolumn{5}{|c|}{ Percentiles } & \multirow{2}{*}{ Max } \\
\hline & & & & $5^{\text {th }}$ & $25^{\text {th }}$ & $50^{\text {th }}$ & $75^{\text {th }}$ & $90^{\text {th }}$ & \\
\hline & & \multicolumn{8}{|c|}{$\mathrm{pH}\left(\mathrm{H}_{2} \mathrm{O}\right)$} \\
\hline \multicolumn{10}{|c|}{ Organic soils } \\
\hline Peat & 37 & $5.0 \pm 0.8$ & 3.5 & 3.9 & 4.3 & 5.1 & 5.6 & 5.9 & 6.5 \\
\hline Mull & 30 & $5.4 \pm 0.6$ & 3.9 & 4.4 & 5.0 & 5.5 & 5.9 & 6.2 & 6.8 \\
\hline \multicolumn{10}{|l|}{ Mineral soils } \\
\hline Heavy Clay & 22 & $5.9 \pm 0.5$ & 5.1 & 5.1 & 5.5 & 5.9 & 6.2 & 6.3 & 6.8 \\
\hline Clay & 48 & $5.7 \pm 0.6$ & 4.0 & 4.9 & 5.2 & 5.6 & 6.0 & 6.6 & 7.0 \\
\hline Medium & 41 & $5.8 \pm 0.5$ & 4.7 & 5.1 & 5.6 & 5.9 & 6.1 & 6.5 & 7.0 \\
\hline \multirow[t]{2}{*}{ Coarse } & 37 & $5.9 \pm 0.6$ & 4.0 & 5.0 & 5.6 & 5.9 & 6.4 & 6.6 & 7.2 \\
\hline & & \multicolumn{8}{|c|}{ SOC (\%) } \\
\hline \multicolumn{10}{|c|}{ Organic soils } \\
\hline Peat & 37 & $36 \pm 9.1$ & 23 & 24 & 27 & 35 & 44 & 47 & 53 \\
\hline Mull & 30 & $16 \pm 3.4$ & 12 & 12 & 13 & 15 & 19 & 21 & 23 \\
\hline \multicolumn{10}{|l|}{ Mineral soils } \\
\hline Heavy Clay & 22 & $4.6 \pm 2.0$ & 2.0 & 2.3 & 3.4 & 4.1 & 4.8 & 8.1 & 8.7 \\
\hline Clay & 48 & $4.3 \pm 2.0$ & 1.0 & 2.1 & 2.9 & 3.7 & 5.4 & 6.7 & 11 \\
\hline Medium & 41 & $2.6 \pm 1.3$ & 0.7 & 0.9 & 1.6 & 2.5 & 3.3 & 4.7 & 6.3 \\
\hline Coarse & 37 & $3.5 \pm 1.9$ & 1.0 & 1.5 & 2.0 & 3.0 & 4.7 & 6.3 & 7.9 \\
\hline
\end{tabular}

Potential CEC varied largely among soil types $\left(4.7-138 \mathrm{cmol}(+) \mathrm{kg}^{-1}\right)$ (Table 4). Comparison of the CEC values revealed that the CEC values in organic soils partly overlapped with those of clay soils, and the CEC values in clay soils partly with other mineral soils. However, the mean CEC values systematically increased with soil types as follows: coarse $\left(14 \mathrm{cmol}(+) \mathrm{kg}^{-1}\right)<$ medium-textured $\left(16 \mathrm{cmol}(+) \mathrm{kg}^{-1}\right)<\operatorname{clay}\left(25 \mathrm{cmol}(+) \mathrm{kg}^{-1}\right)<$ heavy clay $(33 \mathrm{cmol}(+)$ $\left.\mathrm{kg}^{-1}\right)<$ mull $\left(42 \mathrm{cmol}(+) \mathrm{kg}^{-1}\right)<$ peat $\left(77 \mathrm{cmol}(+) \mathrm{kg}^{-1}\right)$ soils. Despite a large variation in TA $\left(0-122 \mathrm{cmol}(+) \mathrm{kg}^{-1}\right)$, the mean values followed the same ascending order as for the CEC in terms of the soil types (Table 5). Mean TA values in mull and peat soils $\left(20-49 \mathrm{cmol}(+) \mathrm{kg}^{-1}\right)$ were 1.8-4.3 times higher than in clay soils $\left(11-12 \mathrm{cmol}(+) \mathrm{kg}^{-1}\right)$, and 3.5-8.3 times higher than in medium-textured or coarse soils $\left(5.4-6.3 \mathrm{cmol}(+) \mathrm{kg}^{-1}\right)$.

Table 4. General statistics for potential cation exchange capacity (CEC, $\mathrm{cmol}^{+}+\mathrm{kg}^{-1}$ ) in different soil types (see number of soil samples $(\mathrm{n})$ in Table 2 and 3 ).

\begin{tabular}{|c|c|c|c|c|c|c|c|c|}
\hline \multirow{2}{*}{ Soil type } & \multirow{2}{*}{ Mean \pm SD } & \multirow{2}{*}{ Min } & \multicolumn{5}{|c|}{ Percentiles } & \multirow{2}{*}{ Max } \\
\hline & & & $5^{\text {th }}$ & $25^{\text {th }}$ & $50^{\text {th }}$ & $75^{\text {th }}$ & $90^{\text {th }}$ & \\
\hline & \multicolumn{8}{|c|}{$\operatorname{CEC}\left(\mathrm{cmol}^{(+)} \mathrm{kg}^{-1}\right)$} \\
\hline \multicolumn{9}{|c|}{ Organic soils } \\
\hline Peat & $77 \pm 28$ & 25 & 47 & 55 & 68 & 104 & 119 & 138 \\
\hline Mull & $42 \pm 13$ & 24 & 25 & 33 & 39 & 46 & 60 & 82 \\
\hline \multicolumn{9}{|l|}{ Mineral soils } \\
\hline Heavy Clay & $33 \pm 6.4$ & 21 & 23 & 29 & 33 & 39 & 40 & 45 \\
\hline Clay & $25 \pm 5.6$ & 13 & 17 & 21 & 24 & 27 & 31 & 44 \\
\hline Medium & $16 \pm 4.6$ & 4.7 & 10 & 12 & 15 & 18 & 22 & 27 \\
\hline Coarse & $14 \pm 4.3$ & 6.4 & 8.0 & 11 & 13 & 17 & 20 & 25 \\
\hline
\end{tabular}

The descriptive statistics are presented for the contents of exchangeable $\mathrm{Ca}^{2+}, \mathrm{Mg}^{2+}, \mathrm{K}^{+}$and $\mathrm{Na}^{+}$in Table 5. As for the mean contents of exchangeable $\mathrm{Ca}^{2+}$, medium-textured and coarse soils had the lowest values $\left(7.2-7.7 \mathrm{cmol}(+) \mathrm{kg}^{-1}\right)$ and organic soils the highest values $\left(17-22 \mathrm{cmol}(+) \mathrm{kg}^{-1}\right)$. The lowestmean contents of exchangeable $\mathrm{Mg}^{2+}$, on average of $1.2 \mathrm{cmol}^{(+)} \mathrm{kg}^{-1}$, were found in medium-textured and coarse soils and the highest $\left(6.1 \mathrm{cmol}(+) \mathrm{kg}^{-1}\right)$ in heavy clay and peat soils. 
Table 5. General statistics for contents $\left(\mathrm{cmol}(+) \mathrm{kg}^{-1}\right)$ of titratable acidity $\left(\mathrm{TA} ; \mathrm{H}^{+}+\mathrm{Al}^{3+}\right)$ and exchangeable calcium $\left(\mathrm{Ca}^{2+}\right)$, magnesium $\left(\mathrm{Mg}^{2+}\right)$, potassium $\left(\mathrm{K}^{+}\right)$and sodium $\left(\mathrm{Na}^{+}\right)$in different soil types (see number of soil samples $(\mathrm{n}$ ) in Table 2 and 3)

\begin{tabular}{|c|c|c|c|c|c|c|c|c|}
\hline \multirow{2}{*}{ Soil type } & \multirow{2}{*}{ Mean \pm SD } & \multirow{2}{*}{ Min } & \multicolumn{5}{|c|}{ Percentiles } & \multirow{2}{*}{ Max } \\
\hline & & & $5^{\text {th }}$ & $25^{\text {th }}$ & $50^{\text {th }}$ & $75^{\text {th }}$ & $90^{\text {th }}$ & \\
\hline & \multicolumn{8}{|c|}{ TA $\left(\mathrm{cmol}^{(+)} \mathrm{kg}^{-1}\right)$} \\
\hline \multicolumn{9}{|c|}{ Organic soils } \\
\hline Peat & $49 \pm 35$ & 4.3 & 12 & 23 & 32 & 76 & 102 & 122 \\
\hline Mull & $20 \pm 12$ & 0.6 & 4.4 & 13 & 20 & 25 & 30 & 59 \\
\hline \multicolumn{9}{|c|}{ Mineral soils } \\
\hline Heavy Clay & $12 \pm 6.7$ & 2.2 & 4.9 & 8.1 & 9.4 & 15 & 22 & 29 \\
\hline Clay & $11 \pm 6.1$ & 1.1 & 2.3 & 6.2 & 9.1 & 15 & 18 & 27 \\
\hline Medium & $6.3 \pm 2.8$ & 0.6 & 2.5 & 4.7 & 5.9 & 7.5 & 9.3 & 15 \\
\hline \multirow[t]{2}{*}{ Coarse } & $5.4 \pm 3.5$ & 0.0 & 1.3 & 3.2 & 4.7 & 6.0 & 9.7 & 18 \\
\hline & \multicolumn{8}{|c|}{$\mathrm{Ca}^{2+}\left(\mathrm{cmol}^{(+)} \mathrm{kg}^{-1}\right)$} \\
\hline \multicolumn{9}{|c|}{ Organic soils } \\
\hline Peat & $22 \pm 12$ & 4.4 & 5.9 & 13 & 19 & 30 & 37 & 53 \\
\hline Mull & $17 \pm 9.9$ & 0.6 & 3.8 & 11 & 15 & 20 & 33 & 39 \\
\hline \multicolumn{9}{|c|}{ Mineral soils } \\
\hline Heavy Clay & $14 \pm 4.3$ & 5.3 & 7.9 & 12 & 14 & 17 & 20 & 22 \\
\hline Clay & $10 \pm 4.7$ & 2.4 & 5.0 & 7.2 & 10 & 13 & 15 & 30 \\
\hline Medium & $7.7 \pm 3.9$ & 1.5 & 1.8 & 5.0 & 7.3 & 8.5 & 14 & 17 \\
\hline \multirow[t]{2}{*}{ Coarse } & $7.2 \pm 4.4$ & 0.8 & 1.2 & 4.4 & 6.1 & 8.6 & 5.0 & 19 \\
\hline & \multicolumn{8}{|c|}{$\mathrm{Mg}^{2+}\left(\mathrm{cmol}(+) \mathrm{kg}^{-1}\right)$} \\
\hline \multicolumn{9}{|c|}{ Organic soils } \\
\hline Peat & $6.1 \pm 4.5$ & 0.5 & 0.8 & 2.7 & 4.9 & 8.7 & 13 & 17 \\
\hline Mull & $4.1 \pm 2.6$ & 0.5 & 0.7 & 2.3 & 3.9 & 6.0 & 6.8 & 11 \\
\hline \multicolumn{9}{|c|}{ Mineral soils } \\
\hline Heavy Clay & $6.1 \pm 2.3$ & 2.2 & 3.2 & 4.3 & 5.9 & 7.7 & 8.9 & 11 \\
\hline Clay & $2.8 \pm 1.5$ & 0.7 & 1.0 & 1.8 & 2.3 & 3.5 & 4.5 & 7.8 \\
\hline Medium & $1.4 \pm 0.7$ & 0.4 & 0.5 & 0.8 & 1.3 & 1.9 & 2.1 & 3.8 \\
\hline \multirow[t]{2}{*}{ Coarse } & $0.9 \pm 0.6$ & 0.2 & 0.2 & 0.5 & 0.8 & 1.2 & 1.6 & 2.9 \\
\hline & \multicolumn{8}{|c|}{$\mathrm{K}^{+}\left(\mathrm{cmol}(+) \mathrm{kg}^{-1}\right)$} \\
\hline \multicolumn{9}{|c|}{ Organic soils } \\
\hline Peat & $0.48 \pm 0.55$ & 0.10 & 0.13 & 0.21 & 0.31 & 0.38 & 1.17 & 2.37 \\
\hline Mull & $0.32 \pm 0.17$ & 0.11 & 0.12 & 0.21 & 0.28 & 0.38 & 0.57 & 0.82 \\
\hline \multicolumn{9}{|l|}{ Mineral soils } \\
\hline Heavy Clay & $0.77 \pm 0.27$ & 0.30 & 0.31 & 0.56 & 0.79 & 0.94 & 1.04 & 1.41 \\
\hline Clay & $0.63 \pm 0.30$ & 0.20 & 0.28 & 0.40 & 0.53 & 0.80 & 1.08 & 1.38 \\
\hline Medium & $0.31 \pm 0.17$ & 0.09 & 0.12 & 0.20 & 0.25 & 0.36 & 0.56 & 0.84 \\
\hline \multirow[t]{2}{*}{ Coarse } & $0.32 \pm 0.19$ & 0.09 & 0.10 & 0.17 & 0.30 & 0.45 & 0.56 & 0.83 \\
\hline & & & & $\mathrm{Na}^{+}(\mathrm{cmc}$ & $\left.\mathrm{kg}^{-1}\right)$ & & & \\
\hline Organic soil & & & & & & & & \\
\hline Peat & $0.20 \pm 0.14$ & 0.05 & 0.07 & 0.11 & 0.17 & 0.24 & 0.42 & 0.59 \\
\hline Mull & $0.14 \pm 0.14$ & 0.03 & 0.05 & 0.07 & 0.11 & 0.14 & 0.21 & 0.70 \\
\hline Mineral soil & & & & & & & & \\
\hline Heavy Clay & $0.16 \pm 0.07$ & 0.06 & 0.10 & 0.12 & 0.16 & 0.19 & 0.20 & 0.40 \\
\hline Clay & $0.13 \pm 0.12$ & 0.00 & 0.03 & 0.10 & 0.10 & 0.14 & 0.21 & 0.77 \\
\hline Medium & $0.14 \pm 0.27$ & 0.00 & 0.00 & 0.06 & 0.10 & 0.12 & 0.17 & 1.80 \\
\hline Coarse & $0.09 \pm 0.07$ & 0.00 & 0.00 & 0.04 & 0.09 & 0.12 & 0.15 & 0.36 \\
\hline
\end{tabular}


The mean contents of exchangeable $\mathrm{K}^{+}$approached an average of $0.70 \mathrm{cmol}(+) \mathrm{kg}^{-1}$ in clay soils, while it averaged $0.36 \mathrm{cmol}(+) \mathrm{kg}^{-1}$ among other soil types. Most soil types had rather similar and very low mean contents of exchangeable $\mathrm{Na}^{+}\left(0.09-0.20 \mathrm{cmol}(+) \mathrm{kg}^{-1}\right)$. In terms of specific cation ratios, the average ratio of exchangeable $\mathrm{Ca}$ to $\mathrm{Mg}$ was 7.5 in coarse, 5.5 in medium-textured, 3.8 in clay and 2.3 in heavy clay soils, and 4.1 in mull and 3.5 in peat soils. The relative proportions of cations and TA varied less between the soil groups than did the absolute concentrations (Table 6). The average TA occupied more than half of potential CEC sites in organic soils, being more abundant than $\mathrm{Ca}^{2+}$, but it was not much lower in mineral soils, where it was around the same level as $\mathrm{Ca}^{2+}$. This outcome highlights the importance of TA as a major component of potential CEC in this soil material. The scarcity of $\mathrm{K}^{+}$in organic soils was also striking.

\begin{tabular}{|c|c|c|c|c|c|}
\hline Soil type & TA & $\mathrm{Ca}^{2+}$ & $\mathrm{Mg}^{2+}$ & $\mathrm{K}^{+}$ & $\mathrm{Na}^{+}$ \\
\hline & & & (\%) & & \\
\hline \multicolumn{6}{|c|}{ Organic soils } \\
\hline Peat & $57 \pm 25$ & $32 \pm 18$ & $9.7 \pm 7.8$ & $0.8 \pm 1.4$ & $0.3 \pm 0.4$ \\
\hline Mull & $49 \pm 23$ & $40 \pm 18$ & $10 \pm 6.1$ & $0.8 \pm 0.4$ & $0.4 \pm 0.3$ \\
\hline \multicolumn{6}{|l|}{ Mineral soils } \\
\hline Heavy Clay & $35 \pm 16$ & $43 \pm 11$ & $19 \pm 6.7$ & $2.4 \pm 1.0$ & $0.5 \pm 0.2$ \\
\hline Clay & $42 \pm 19$ & $43 \pm 17$ & $11 \pm 5.4$ & $2.6 \pm 1.2$ & $0.5 \pm 0.5$ \\
\hline Medium & $41 \pm 16$ & $47 \pm 16$ & $9.0 \pm 4.5$ & $2.0 \pm 1.0$ & $0.9 \pm 1.8$ \\
\hline Coarse & $41 \pm 22$ & $49 \pm 20$ & $6.9 \pm 4.2$ & $2.4 \pm 1.4$ & $0.7 \pm 0.8$ \\
\hline
\end{tabular}

\section{Linear regression models for estimating cation exchange capacity (CEC)}

STCat $\left(\mathrm{cmol}(+) \mathrm{I}^{-1}\right)$ extracted with acid ammonium acetate soil test solution and soil $\mathrm{pH}$ explained $83 \%$ of the variation in the CEC (eq. 1; Table 7). When the two major soil types (organic and mineral soils) were analyzed separately, pH and STCat explained $89 \%$ of the variation in CEC in mineral soils (eq. 3 ) and root mean square error (RMSE) decreased to 3.21, whereas in organic soils, RMSE was above 8 (eq. 8) (Table 7, Fig. 1). Validation of the models with independent dataset produced relatively good agreement with observed and predicted values for mineral and organic soils $\left(R^{2}=0.69\right.$ and 0.83 , respectively, Table 7$)$. The functions, however, slightly underestimated CEC $(\mathrm{ME}<0)$ in mineral soils (Table 7, Fig. 1).

Table 7. Pedotransfer functions for estimating potential cation exchange capacity (CEC, $\left.\mathrm{cmol}^{(+)} \mathrm{kg}^{-1}\right)$ using sum of soil test cations (STCat cmol $(+)^{-1}=$ STCa cmol I-1 $\left.\times 2+\mathrm{STMg} \mathrm{cmol} \mathrm{I}^{-1} \times 2+\mathrm{STK} \mathrm{cmol} \mathrm{I}^{-1}\right), \mathrm{pH}$ and soil organic carbon (SOC, \%) as explanatory variables, and statistics of calibration data and validation data

\begin{tabular}{|c|c|c|c|c|c|c|c|c|c|}
\hline \multirow{2}{*}{$\frac{\text { CEC }}{\text { Eq. No. }}$} & \multirow[b]{2}{*}{ Predictors } & \multirow[b]{2}{*}{ Regression equation } & \multicolumn{3}{|c|}{ Calibration } & \multicolumn{4}{|c|}{ Validation } \\
\hline & & & $\mathrm{n}$ & RMSE & $\mathrm{R}^{2}$ & $\mathrm{n}$ & RMSE & ME & $\mathrm{R}^{2}$ \\
\hline & All soils & & & & & & & & \\
\hline 1 & STCat, $\mathrm{pH}$ & $\mathrm{CEC}=145.68+1.91 \times$ STCat $-24.36 \times \mathrm{pH}$ & 63 & 7.71 & 0.83 & 24 & 8.88 & -0.18 & 0.78 \\
\hline \multirow[t]{2}{*}{2} & STCat, $\mathrm{pH}, \mathrm{SOC}$ & $\mathrm{CEC}=70.97+1.25 \times$ STCat $-11.40 \times \mathrm{pH}+0.71 \times \mathrm{SOC}$ & 63 & 3.95 & 0.96 & 24 & 6.16 & -0.10 & 0.85 \\
\hline & Mineral soils & & & & & & & & \\
\hline 3 & STCat, $\mathrm{pH}$ & CEC $=82.88+1.30 \times$ STCat $-12.97 \times p H$ & 29 & 3.21 & 0.89 & 15 & 7.05 & -0.30 & 0.69 \\
\hline 4 & STCat, $\mathrm{pH}, \mathrm{SOC}$ & $\mathrm{CEC}=50.83+1.17 \times$ STCat $-8.38 \times \mathrm{pH}+1.48 \times \mathrm{SOC}$ & 29 & 2.26 & 0.95 & 15 & 6.72 & -0.16 & 0.62 \\
\hline 5 & SOC & $\mathrm{CEC}=11.23+2.41 \times \mathrm{SOC}$ & 114 & 7.00 & 0.33 & & & & \\
\hline 6 & Clay & CEC $=10.29+0.31 \times$ Clay & 114 & 4.37 & 0.74 & 34 & 6.26 & -0.10 & 0.66 \\
\hline \multirow[t]{2}{*}{7} & SOC, Clay & $\mathrm{CEC}=4.89+1.67 \times \mathrm{SOC}+0.27 \times$ Clay & 114 & 2.89 & 0.89 & 34 & 6.39 & -0.14 & 0.82 \\
\hline & Organic Soils & & & & & & & & \\
\hline 8 & STCat, $\mathrm{pH}$ & CEC $=147.84+1.98 \times$ STCat $-24.60 \times p H$ & 34 & 8.42 & 0.72 & 9 & 4.94 & 0.08 & 0.83 \\
\hline 9 & STCat, $\mathrm{pH}, \mathrm{SOC}$ & $\mathrm{CEC}=78.47+1.33 \times \mathrm{STCat}-12.95 \times \mathrm{pH}+0.69 \times \mathrm{SOC}$ & 34 & 4.98 & 0.90 & 9 & 4.12 & -0.02 & 0.86 \\
\hline 10 & SOC & $\mathrm{CEC}=17.17+1.51 \times \mathrm{SOC}$ & 46 & 16.56 & 0.54 & 20 & & & \\
\hline 11 & $\mathrm{SOC}, \mathrm{pH}$ & $\mathrm{CEC}=70.10+1.30 \times \mathrm{SOC}-9.11 \times \mathrm{pH}$ & 46 & 15.37 & 0.62 & 20 & & & \\
\hline
\end{tabular}



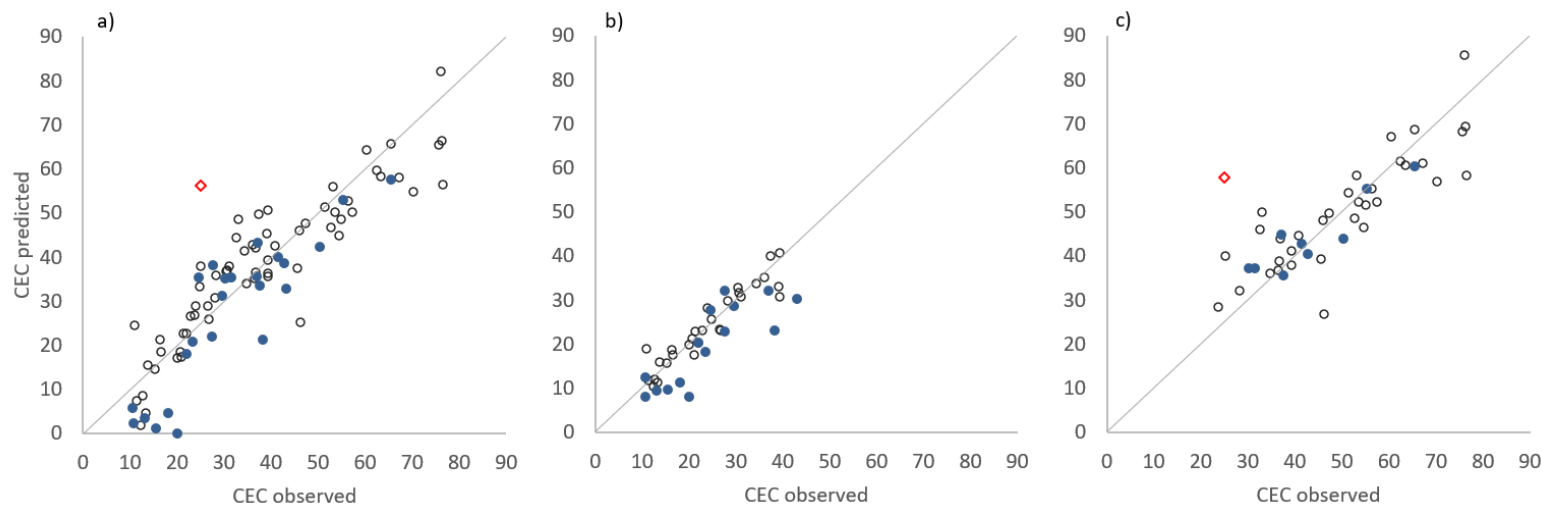

Fig. 1. Predicted cation exchange capacity $\left(\mathrm{CEC}, \mathrm{cmol}(+) \mathrm{kg}^{-1}\right.$ ) modelled using soil test cations (STCat $\mathrm{cmol}(+) \mathrm{l}^{-1}=\mathrm{STCa} \mathrm{cmol}$ $\left.\mathrm{I}^{-1} \times 2+\mathrm{STMg} \mathrm{cmol} \mathrm{I}^{-1} \times 2+\mathrm{STK} \mathrm{cmol}^{-1}\right)$ and $\mathrm{pH}$ as predictors for a) the whole data, b) for mineral soils and c) for organic soils plotted against observed $\mathrm{CEC}\left(\mathrm{cmol}(+) \mathrm{kg}^{-1}\right)$. Open circles represent the results of the calibration data and blue circles represent the validation data. Data point excluded from the regression analysis as an outlier is marked with red square.

Including SOC in the model increased the explanation power of the regression model such that the STCat, pH and SOC explain $96 \%$ of the variation in the CEC in all soil types (eq. 2; Table 7, Fig. 2). The validation data showed good agreement between the observed and predicted values $\left(R^{2}=0.85\right.$, Table 7$)$, and further, the absolute value of the ME of the validation data was lower, though still below 0 .

In mineral soils, SOC solely explained $33 \%$ of the variation (eq. 5) and pH was not a statistically significant predictor when included in the model with SOC. In contrast for the organic soils, including $\mathrm{pH}$ in the model with SOC resulted in both variables to be statistically significant and increased the explanatory power from $54 \%$ (eq. 10) to $62 \%$ (eq. 11).
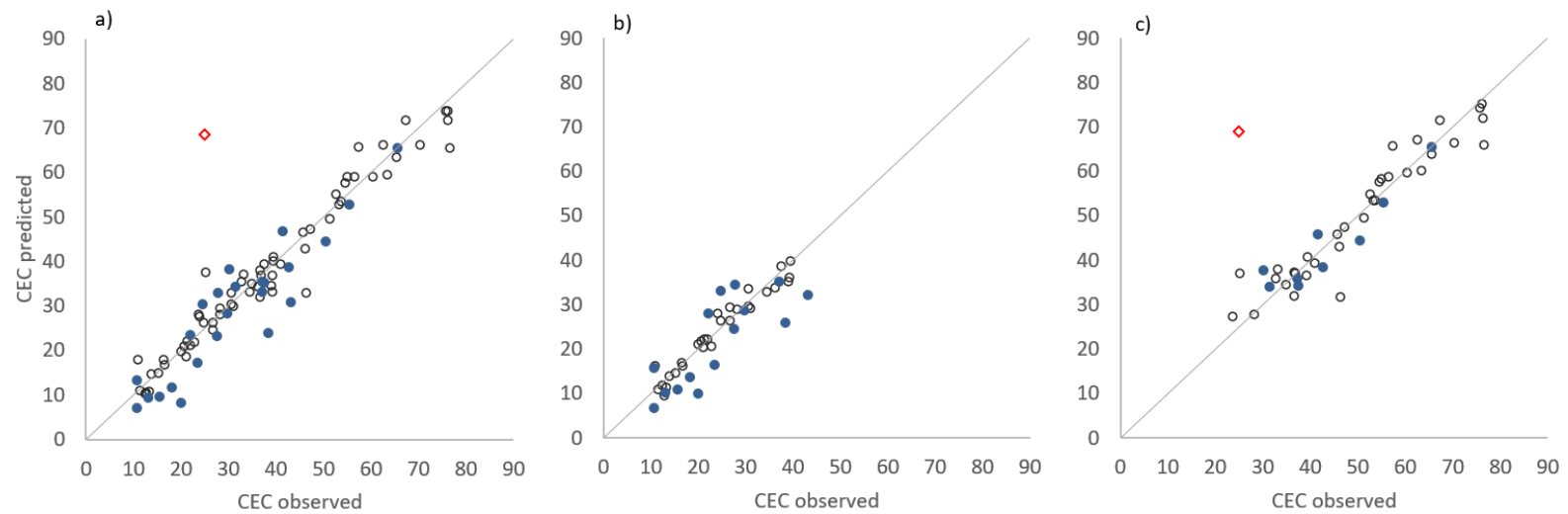

Fig. 2. Predicted cation exchange capacity $\left(\mathrm{CEC}, \mathrm{cmol}(+) \mathrm{kg}^{-1}\right)$ modelled using soil test cations $\left(\mathrm{STCat} \mathrm{cmol}(+) \mathrm{I}^{-1}=\mathrm{STCa}\right.$ $\left.\mathrm{cmoll}^{-1} \times 2+\mathrm{STMg} \mathrm{cmol}^{-1} \times 2+\mathrm{STK} \mathrm{cmol}^{-1}\right), \mathrm{pH}$ and soil organic carbon (SOC, \%) as predictors for a) the whole data, b) for mineral soils and c) for organic soils plotted against observed CEC $\left(\mathrm{cmol}(+) \mathrm{kg}^{-1}\right)$. Open circles represent the results of the calibration data and blue circles represent the validation data. Data point excluded from the regression analysis as an outlier is marked with red square.

In mineral soils, $74 \%$ of the variation in CEC was explained by clay content (eq. 6) and together with SOC, clay explained $89 \%$ of the variation in CEC (eq. 7) (Table 7, Fig. 3). Soil pH showed not to be a statistically significant predictor when included in the model. The regression coefficients indicated CECs of $27 \mathrm{cmol}(+) \mathrm{kg}^{-1}$ for clay and 167 $\mathrm{cmol}(+) \mathrm{kg}^{-1}$ for SOC. For the validation dataset, the strength of the linear relationship $\left(\mathrm{R}^{2}\right)$ between observed values and values predicted using eq. 7 (Table 7) was 0.82 , and ME indicated potential underestimation of the CEC (Table 7, Fig. 3). 

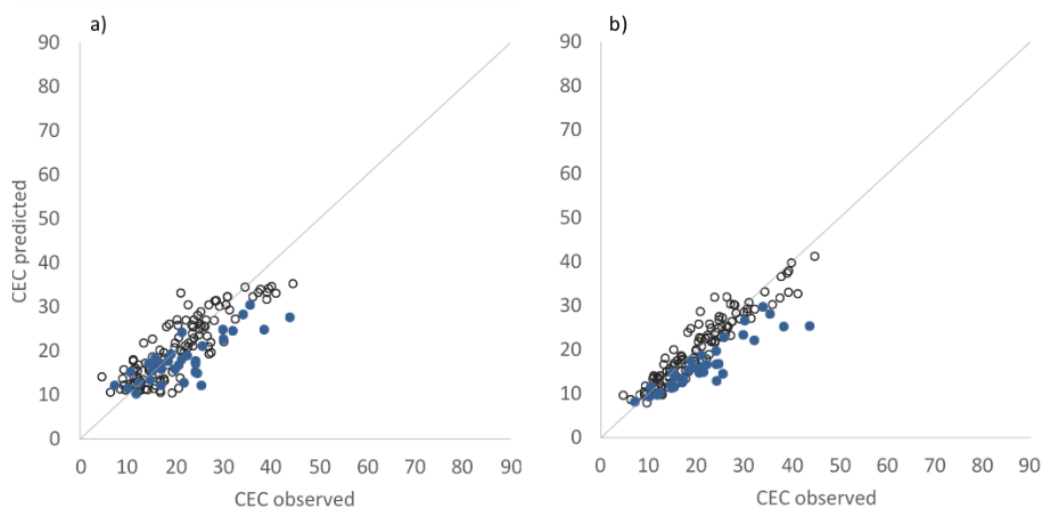

Fig. 3. Predicted cation exchange capacity (CEC, $\left.\mathrm{cmol}(+) \mathrm{kg}^{-1}\right)$ in mineral soils modelled using a) clay (\%) and b) clay and soil organic carbon (SOC, \%) as predictors plotted against observed CEC $\left(\mathrm{cmol}(+) \mathrm{kg}^{-1}\right)$. Open circles represent the results of the calibration data and blue circles represent the validation data.

\section{Linear regression models for estimating titratable acidity (TA)}

Soil pH and SOC explained the majority of the TA (eq. 12-16, Table 8, Fig. 4 and 5). In minerals soils, including the clay content in the explanatory variables (eq. 15) increased $\mathrm{R}^{2}$ and reduced the RMSE (Table 8, Fig. 5). Validation of the developed TA models with independent dataset indicated that eq. 13 for all soils and eq. 15 for mineral soils produced best agreement with observed and predicted values estimated based on MRSE and $R^{2}$ (Table 8 , Fig. 4 and 5). The validation data indicated risk for equations 12 and 14-16 to underestimate the TA (Table 8).

Table 8. Pedotransfer functions for estimating titratable acidity (TA, $\left.\mathrm{cmol}(+) \mathrm{kg}^{-1}\right)$ using soil organic carbon (SOC, \%), pH and clay content (\%, for mineral soils) as explanatory variables, and statistics of calibration data and validation data

\begin{tabular}{|c|c|c|c|c|c|c|c|c|c|}
\hline \multirow{2}{*}{$\begin{array}{c}\text { TA } \\
\text { Eq. No. }\end{array}$} & \multirow[b]{2}{*}{ Predictors } & \multirow[b]{2}{*}{ Regression equation } & \multicolumn{3}{|c|}{ Calibration } & \multicolumn{4}{|c|}{ Validation } \\
\hline & & & $\mathrm{n}$ & RMSE & $\mathrm{R}^{2}$ & $\mathrm{n}$ & RMSE & ME & $\mathrm{R}^{2}$ \\
\hline & All soils & & & & & & & & \\
\hline \multirow[t]{2}{*}{12} & $\mathrm{SOC}, \mathrm{pH}$ & $\operatorname{SQRT}(T A)=10.97+0.067 \times \mathrm{SOC}-1.45 \times \mathrm{pH}$ & 159 & 0.69 & 0.84 & 53 & 0.86 & -0.003 & 0.93 \\
\hline & & $\mathrm{TA}=(10.97+0.067 \times \mathrm{SOC}-1.45 \times \mathrm{pH})^{2}$ & & 6.76 & & & & & \\
\hline \multirow[t]{3}{*}{13} & $\mathrm{SOC}, \mathrm{pH}, \mathrm{SOC} \times \mathrm{pH}$ & $\mathrm{SQRT}(\mathrm{TA})=9.19+0.20 \times \mathrm{SOC}-1.13 \times \mathrm{pH}-0.02 \times \mathrm{pH} \times \mathrm{SOC}$ & 159 & 0.65 & 0.86 & 53 & 0.64 & 0.004 & 0.93 \\
\hline & & $\mathrm{TA}=(9.19+0.20 \times \mathrm{SOC}-1.13 \times \mathrm{pH}-0.02 \times \mathrm{pH} \times \mathrm{SOC})^{2}$ & & 5.87 & & & & & \\
\hline & Mineral soils & & & & & & & & \\
\hline \multirow[t]{2}{*}{14} & $\mathrm{SOC}, \mathrm{pH}$ & $\operatorname{SQRT}(T A)=7.523+0.200 \times \mathrm{SOC}-0.946 \times \mathrm{pH}$ & 112 & 0.50 & 0.72 & 34 & 0.45 & -0.002 & 0.71 \\
\hline & & $\mathrm{TA}=(7.523+0.200 \times \mathrm{SOC}-0.946 \times \mathrm{pH})^{2}$ & & 2.97 & & & & & \\
\hline \multirow[t]{3}{*}{15} & SOC, Clay, pH & $\operatorname{SQRT}(\mathrm{TA})=7.282+0.162 \times \mathrm{SOC}+0.012 \times$ Clay $-0.952 \times \mathrm{pH}$ & 112 & 0.41 & 0.81 & 34 & 0.43 & -0.005 & 0.77 \\
\hline & & $\mathrm{TA}=(7.28+0.16 \times \mathrm{SOC}+0.01 \times \text { Clay }-0.95 \times \mathrm{pH})^{2}$ & & 2.23 & & & & & \\
\hline & Organic soils & & & & & & & & \\
\hline \multirow[t]{2}{*}{16} & $\mathrm{SOC}, \mathrm{pH}$ & $\operatorname{SQRT}(T A)=15.030+0.051 \times \mathrm{SOC}-2.138 \times \mathrm{pH}$ & 46 & 0.78 & 0.87 & 19 & 1.04 & -0.041 & 0.95 \\
\hline & & $\mathrm{TA}=(15.030+0.051 \times \mathrm{SOC}-2.138 \times \mathrm{pH})^{2}$ & & 11.6 & & & & & \\
\hline
\end{tabular}
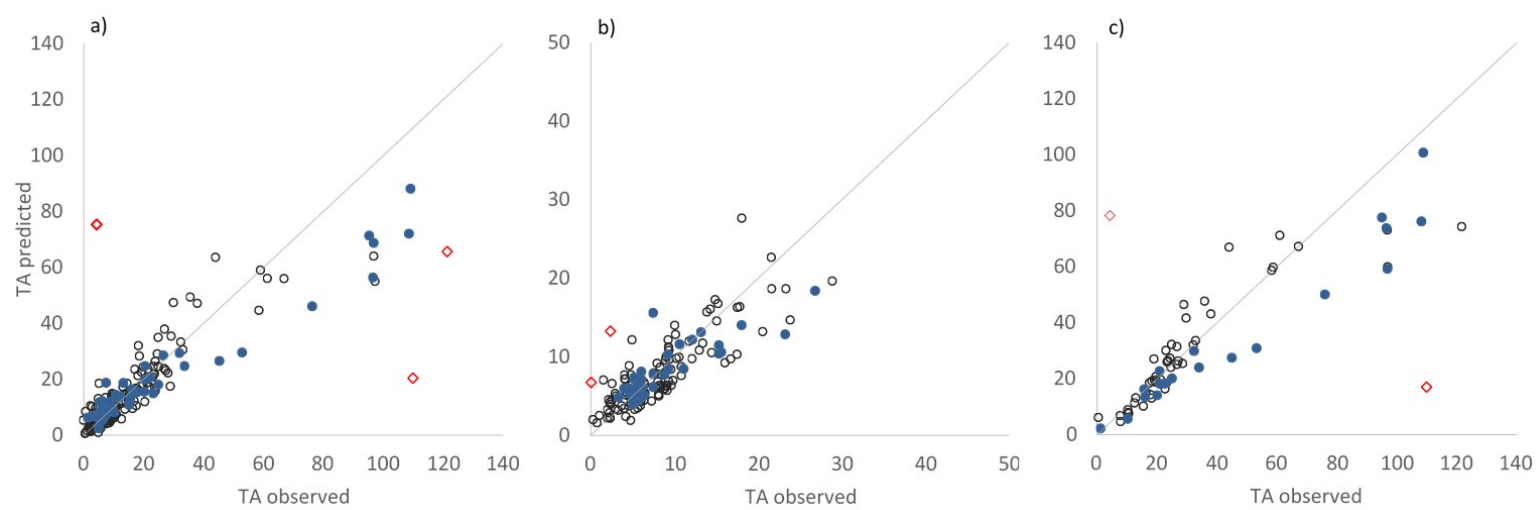

Fig. 4. Predicted titratable acidity ( $\left.\mathrm{TA}, \mathrm{cmol}(+) \mathrm{kg}^{-1}\right)$ modelled using $\mathrm{pH}$ and soil organic carbon (SOC, \%) as predictors for a) whole data, b) for mineral soils and c) for organic soils plotted against observed TA ( $\left.\mathrm{cmol}(+) \mathrm{kg}^{-1}\right)$. Open circles represent the results of the calibration data and blue circles represent the validation data. Data points excluded from the regression analysis as outliers are marked with red squares. 

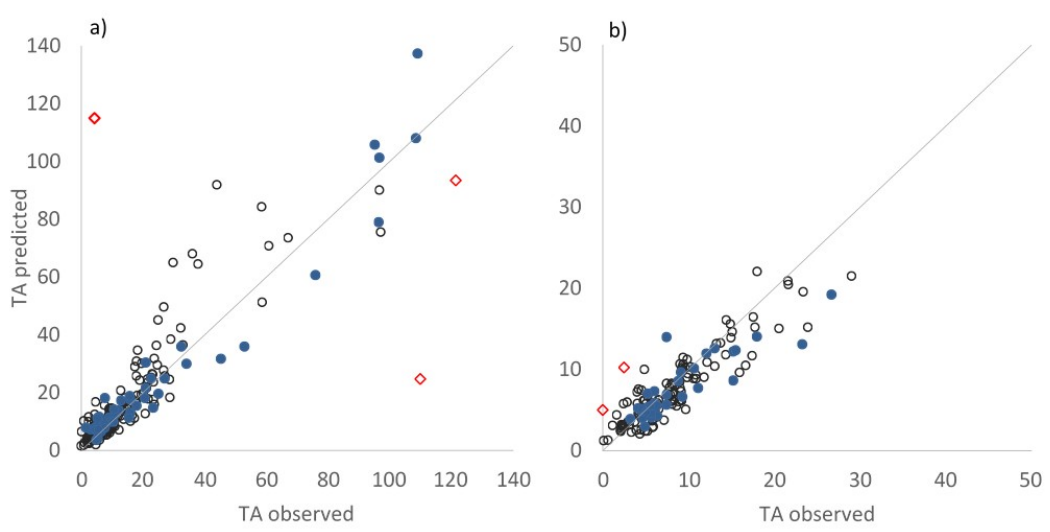

Fig. 5. Predicted titratable acidity (TA, $\left.\mathrm{cmol}(+) \mathrm{kg}^{-1}\right)$ modelled using a) $\mathrm{pH}$, soil organic carbon (SOC, \%) and $\mathrm{pH} \times \mathrm{SOC}$ as predictors for whole data and $\mathrm{b}$ ) $\mathrm{pH}$, clay and SOC for mineral soils plotted against observed TA $\left(\mathrm{cmol}(+) \mathrm{kg}^{-1}\right)$. Open circles represent the results of the calibration data and blue circles represent the validation data. Data points excluded from the regression analysis as outliers are marked with red squares.

\section{Linear regression models for estimating clay content with soil test cations and $\mathrm{pH}$}

Together with pH, STCa, STMg and STK explained 76\% of the variation in clay\% in mineral soils (eq. 17) (Table 9, Fig. 6) and including SOC in explanatory variables further improved the explanatory power of the model (eq. 18) (Table 9, Fig. 7). Regression models fitted separately for clay soils and coarse mineral soils revealed that clay\% estimation for coarse soils was uncertain. Including SOC in the model improved the model for coarse soils but still only $46 \%$ of the variation was explained (eq. 22 and 23). For the clay soils, STCat and soil pH explained $78 \%$ of the variation and SOC was not statistically significant as an explanatory variable (eq. 21). Soil test cations were included separately as the share of Mg increased with increasing clay content, whereas the share of Ca decreased (Fig. 7). Explaining FINES content with soil test variables turned out to be uncertain and only 50 or $53 \%$ of the variation in FINES content could be explained with STCat and pH or STCat, pH and SOC, respectively (eq. 19 and 20) (Table 8). Validation of the equations 17, 18 and 21 with independent dataset produced larger RMSE's and in addition, the validation data pointed towards a risk for underestimating the clay content (Table 8).

Table 9. Pedotransfer functions for estimating mineral soil clay content (\%) and FINES content (\%, fine-sized particles; $\varnothing<0.02 \mathrm{~mm})$ using soil test cations (STCa, $\mathrm{cmol} \mathrm{I}^{-1}$; STMg, $\mathrm{cmol} \mathrm{I}^{-1}$; STK, $\mathrm{cmol} \mathrm{I}^{-1}$ ) $\mathrm{pH}$ and soil organic carbon (SOC, \%) as explanatory variables, and statistics of calibration data and validation data

\begin{tabular}{|c|c|c|c|c|c|c|c|c|c|}
\hline \multirow{2}{*}{$\frac{\text { Clay/Fines }}{\text { Eq. no. }}$} & \multirow[b]{2}{*}{ Predictors } & \multirow[b]{2}{*}{ Regression equation } & \multicolumn{3}{|c|}{ Calibration } & \multicolumn{4}{|c|}{ Validation } \\
\hline & & & $\mathrm{n}$ & RMSE & $\mathrm{R}^{2}$ & $\mathrm{n}$ & RMSE & ME & $\mathrm{R}^{2}$ \\
\hline & All soils & & & & & & & & \\
\hline 17 & $\mathrm{Mg}, \mathrm{Ca}, \mathrm{K}, \mathrm{pH}$ & $\begin{array}{l}\text { Clay }=72.62+24.23 \times \operatorname{sqrt}(\mathrm{Mg})+4.32 \times \mathrm{Ca}+ \\
17.15 \times \mathrm{K}-16.13 \times \mathrm{pH}\end{array}$ & 571 & 9.38 & 0.76 & 31 & 10.72 & -0.23 & 0.79 \\
\hline 18 & $\mathrm{Mg}, \mathrm{Ca}, \mathrm{K}, \mathrm{pH}, \mathrm{SOC}$ & $\begin{array}{l}\text { Clay }=116.54+24.17 \times \operatorname{sqrt}(\mathrm{Mg})+5.82 \times \mathrm{Ca}+ \\
13.29 \times \mathrm{K}-22.80 \times \mathrm{pH}-2.37 \times \mathrm{SOC}\end{array}$ & 571 & 8.54 & 0.80 & 31 & 10.61 & -0.16 & 0.74 \\
\hline 19 & $\mathrm{Mg}, \mathrm{Ca}, \mathrm{K}, \mathrm{pH}$ & $\begin{array}{l}\text { Fines }=105.77+34.35 \times \operatorname{sqrt}(\mathrm{Mg})+5.16 \times \mathrm{Ca}+ \\
10.34 \times \mathrm{K}-19.35 \times \mathrm{pH}\end{array}$ & 571 & 19.98 & 0.50 & & & & \\
\hline \multirow[t]{2}{*}{20} & $\mathrm{Mg}, \mathrm{Ca}, \mathrm{pH}, \mathrm{SOC}$ & $\begin{array}{l}\text { Fines }=168.07+35.37 \times \operatorname{sqrt}(\mathrm{Mg})+7.41 \times \mathrm{Ca}- \\
28.85 \times \mathrm{pH}-3.28 \times \mathrm{SOC}\end{array}$ & 571 & 19.31 & 0.53 & & & & \\
\hline & Clay soils & & & & & & & & \\
\hline \multirow[t]{2}{*}{21} & $\mathrm{Mg}, \mathrm{Ca}, \mathrm{K}, \mathrm{pH}$ & $\begin{array}{l}\text { Clay }=82.08+21.52 \times \operatorname{sqrt}(\mathrm{Mg})+2.76 \times \mathrm{Ca}+ \\
10.30 \times \mathrm{K}-13.83 \times \mathrm{pH}\end{array}$ & 146 & 6.52 & 0.78 & 28 & 9.03 & -0.13 & 0.73 \\
\hline & Coarse soils & & & & & & & & \\
\hline 22 & $\mathrm{Mg}, \mathrm{Ca}, \mathrm{K}, \mathrm{pH}$ & $\begin{array}{l}\text { Clay }=33.53+6.08 \times \mathrm{Mg}+2.39 \times \mathrm{Ca}+8.70 \times \\
\mathrm{K}-6.32 \times \mathrm{pH}\end{array}$ & 425 & 6.55 & 0.34 & & & & \\
\hline 23 & $\mathrm{Mg}, \mathrm{Ca}, \mathrm{K}, \mathrm{pH}, \mathrm{SOC}$ & $\begin{array}{l}\text { Clay }=71.52+8.28 \times \mathrm{Mg}+3.78 \times \mathrm{Ca}+6.81 \times \mathrm{K} \\
-12.54 \times \mathrm{pH}-1.75 \times \mathrm{SOC}\end{array}$ & 425 & 5.94 & 0.46 & & & & \\
\hline
\end{tabular}



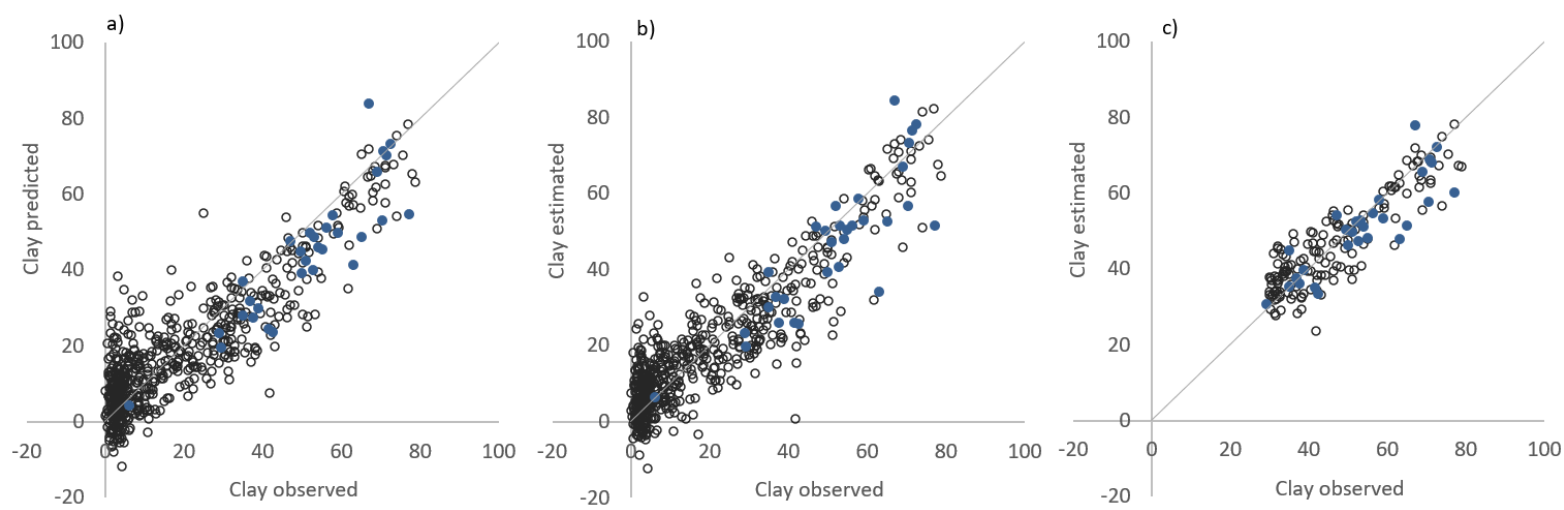

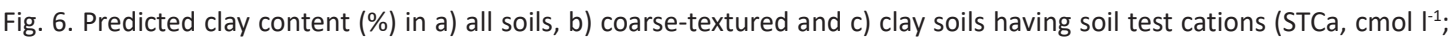
STMg, $\mathrm{cmol} \mathrm{I}^{-1}$; STK, $\mathrm{cmol} \mathrm{I}^{-1}$ ) and pH as explanatory variables plotted against observed clay content. Open circles represent the results of the calibration data and blue circles represent the validation data.

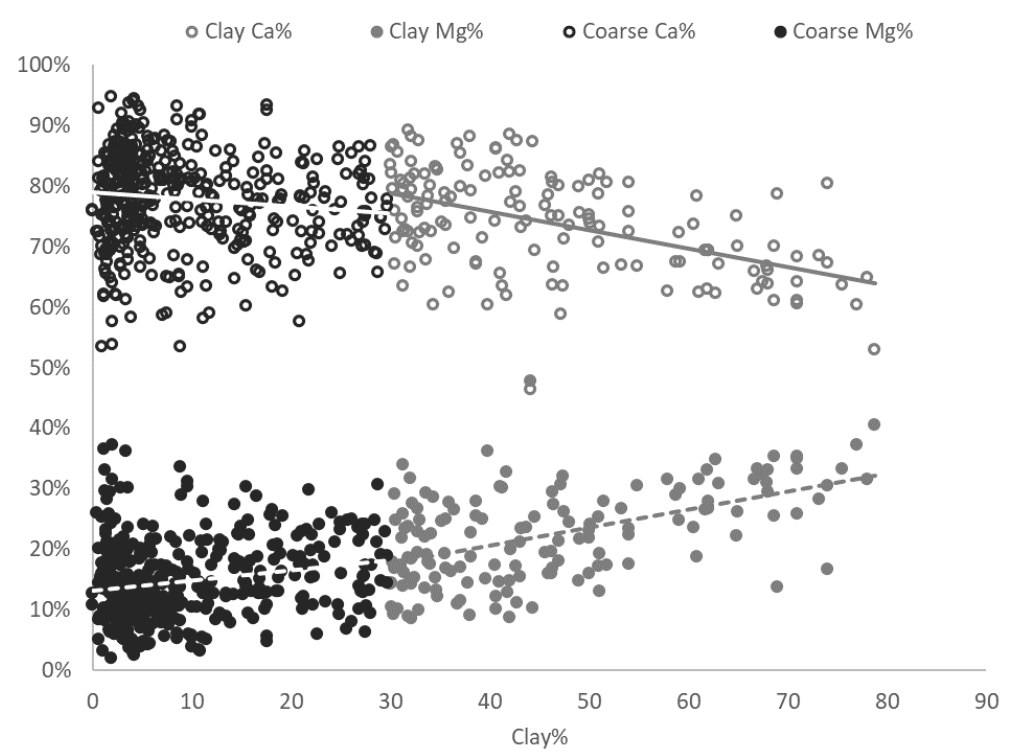

Fig. 7. The share of $\mathrm{Ca}$ and $\mathrm{Mg}$ of the total soil test cations (STCa, $\mathrm{cmol}^{-1}$; STMg, $\mathrm{cmol}^{-1}$; STK, $\mathrm{cmol}^{-1}$ ) plotted against clay content in coarse- and medium-textured soils and clay soils.

\section{Discussion}

The basic soil test data available on farms at field level, i.e. plant available cations (STCat) and pH were found to explain $83 \%$ of the variation in CEC. This was anticipated, as the soil test procedure (AAAc, pH 4.65) extracts around $80 \%$ of the total exchangeable cations (Vuorinen and Mäkitie 1955) and pH links to exchangeable acidity as described below. Previously, Niskanen and Jaakkola (1986) congruently reported STCat and pH to explain over $80 \%$ of the variation in effective CEC in soils from Helsinki, Finland. Including information on SOC in the current model increased the explanatory power up to $96 \%$. Organic matter is known to exhibit a major contribution to CEC, and organic compounds may even reduce the relative contribution of the clay fraction by blocking of the negative charges (e.g. Syers et al. 1970, Parfitt et al. 1995, Seybold et al. 2005). However, in the mineral soils of the current study, clay alone explained $74 \%$ of the variation in CEC, and with SOC the explanatory power increased to $89 \%$. Similarly, in Danish soils, $90 \%$ of the variability in CEC values could be modelled by clay and organic matter content (Krogh et al. 2000), whereas in Iran, the explanatory power of SOM, clay and sand on CEC was $97 \%$ (Fooladmand 2008). The average CEC attained for clay in the present study $\left(27 \mathrm{cmol}(+) \mathrm{kg}^{-1}\right)$ is in the range typical of illite as the predominant mineral (e.g. Martel et al. 1978, Kahr and Madsen 1995, White 1997). For SOC, the corresponding value of $167 \mathrm{cmol}(+) \mathrm{kg}^{-1}$ agrees with the value of $184 \mathrm{cmol}(+) \mathrm{kg}^{-1} \mathrm{SOC}$ reported for unfractionated soil materials by Thompson et al. (1989), but also considerably higher values have been reported, e.g. $284-291 \mathrm{cmol}^{(+)} \mathrm{kg}^{-1}$ organic matter found by Krogh et al. (2000) in Denmark. 
The potential CEC extracted by neutral ammonium acetate (TA determined by back-titration to $\mathrm{pH}$ 7.0) varied considerably among the different soil types. In mineral soils (CEC $14-33 \mathrm{cmol}(+) \mathrm{kg}^{-1}$ ), the means and trends in soil CEC appeared to be similar to previously reported values for topsoils and subsoils of cultivated and virgin mineral soils (Kaila 1971a, 1972, Sippola 1974, Martel et al. 1978, Niskanen and Jaakkola 1986, Manrique et al. 1991, Krogh et al. 2000). In terms of different soils grouped by their taxonomic order, Manrique et al. (1991) found the means of potential CEC to range between $8.9 \mathrm{cmol}(+) \mathrm{kg}^{-1}$ for Oxisols $(n=299)$ and $38 \mathrm{cmol}(+) \mathrm{kg}^{-1}$ for Vertisols $(n=1274)$. In the present study, the means of potential CEC also followed the typical increasing trend with an increase in clay content among soil types (Kaila 1972, Sippola 1974).

In productive agricultural soils, the distribution of major cations is generally considered to be $\mathrm{Ca}^{2+}>\mathrm{Mg}^{2+}>\mathrm{K}^{+}$ $>\mathrm{Na}^{+}$(e.g. Graham 1959, Bohn et al. 2001). In terms of basic cations of the present study, the average degree of base saturation of potential CEC was higher in mineral (60\%) than in organic (47\%) soils, and the distribution of base cations and the $\mathrm{Ca}$ to $\mathrm{Mg}$ ratio followed the typical trends. In the plough layer of Finnish mineral soils, Kaila (1972) found exchangeable $\mathrm{Ca}^{2+}$ to be the dominant cation (mean 61-78\%), being followed by $\mathrm{Mg}^{2+}(9-30 \%)$, $\mathrm{K}^{+}(3-5 \%)$ and $\mathrm{Na}^{+}(1-2 \%)$. In the same study, the mean ratio of $\mathrm{Ca}$ to $\mathrm{Mg}$ decreased from about 9 in sand soils to about 2 in heavy clay soils (Kaila 1972). Similarly, in our data, the $\mathrm{Mg}^{2+}$ appeared to occupy more CEC sites than $\mathrm{Ca}^{2+}$ with increasing clay content. Acid soils are also characterized by exchangeable aluminum $\left(\mathrm{Al}^{3+}\right)$ and hydrogen $\left(\mathrm{H}^{+}\right)$, although rarely being the predominant cations (Bohn et al. 2001). In the present study, however, the prominent or predominant part of potential CEC was occupied by the TA in mineral (mean 35-42\%) and organic (mean 49-57\%) soils.

For a farmer, an estimate of the TA component of the potential CEC may be of more use than the estimate of the potential CEC as a whole, since the acidity reveals the extent of binding sites that could be released for nutrient cations by neutralization with liming. The TA comprises exchangeable $\mathrm{Al}^{3+}$ and $\mathrm{H}^{+}$often determined in unbuffered $\mathrm{KCl}$ extracts (Coscione et al. 1998, Dai and Richter 2000) and in addition, $\mathrm{pH}$-dependent dissociation of $\mathrm{H}^{+}$from the functional groups in organic matter and edges of clay minerals and release of adsorbed hydroxy-Al cations (Bache 1976). Besides the $\mathrm{pH}$-dependent acidity, soil $\mathrm{pH}$ is related to the amount of exchangeable $\mathrm{Al}^{3+}$, which tends to decrease with increase in soil pH due to formation of Al oxides (Cabrera and Talibudeen 1977). Organic matter is known to complex Al and thus control its amounts and lability in soil (Cabrera and Talibudeen 1977, Wesselink et al. 1996). These relationships explain the observed contribution of SOC, $\mathrm{pH}$ and clay on the TA such that an increase in SOC or clay increases, and an increase in $\mathrm{pH}$ decreases the amount of TA. The mean contents of TA in the present study were comparable to those in Kaila (1971b), who reported the mean TA of about 9, 12 and 49 $\mathrm{cmol}(+) \mathrm{kg}^{-1}$ for Finnish coarse $(n=141)$, clay $(n=100)$ and organic $(n=57)$ soils, respectively. In the study of Kaila (1971b), the average titratable, nonexchangeable acidity extracted by $\mathrm{KCl}$ at $\mathrm{pH} 8.2$ was about 8-12 times higher within the soil groups than the corresponding exchangeable acidity displaced by unbuffered KCl. Kaila (1972) and Niskanen and Jaakkola (1986) found that exchangeable acidity displaced by unbuffered $\mathrm{KCl}$ had a relatively minor importance in most soil groups ( $<10 \%$ of effective CEC).

On a weight basis, the highest CEC values are generally reported for the organic soils among the soil types due to the lower bulk densities. Previous studies have shown a markedly higher mean or median CEC as well as larger variation in CEC values in organic soils than those of mineral soils (e.g. Krogh et al. 2000). In the present study, the variation in potential CEC values $\left(24-138 \mathrm{cmol}(+) \mathrm{kg}^{-1}\right)$ of organic soils was somewhat smaller when compared with the range of 22-257 $\mathrm{cmol}(+) \mathrm{kg}^{-1}$ (median $\left.61 \mathrm{cmol}(+) \mathrm{kg}^{-1}\right)$ obtained for Danish organic soils $(\mathrm{SOM}>10 \%, \mathrm{n}=$ 68 ) by Krogh et al. (2000).

\section{Use of soil test data to unravel soil clay content}

Methods used for analyzing clay content are known to be laborious and therefore costly and thus, not feasible in surveys where large numbers of samples are analyzed. In routine soil tests for farmers, soil texture is determined by sensory identification (finger assessment) and reported to the farmer on a nominal scale as a soil type included in the Finnish soil texture triangle (Halonen and Juusela 1957). Clay soils are classified as clays or heavy clays having clay content of $30-60 \%$ or above $60 \%$, respectively. Our results showed that for clay soils, the clay content can be estimated relatively well with soil test data obtainable for most of the fields in Finland. However, for coarse textured soils, where SOM contributes significantly to cation exchange sites, the use of STCat in estimating clay content might result in a significant error.

Arthur et al. (2015) reported regression relationships for estimating clay content based on the link between hygroscopic water and clay content. Their models predicted clay contents well for most soils (RMSE varying between 
3-6\%), however, large SOC and prevalence of 1:1 clay minerals in soil increased the prediction error of the equations (Arthur et al. 2015). The high SOC content has a larger effect in medium- and coarse-textured soils where SOC significantly increases the specific surface area of the soil whereas in clay soils, the contribution of SOC to sorption sites becomes insignificant compared with that of clay as the clay content increases. The SOC content of mineral soils in our data set was relatively high, the mean being $2.6 \%$ and $3.5 \%$ also in medium- and coarsetextured soils, respectively. According to Arthur et al. (2015), in soils with SOC\% higher than 2.4, there is a risk of a consistent increase in prediction error with increasing SOC contents especially in low clay soils. Predicting clay content based on Finnish soil test data resulted in larger RMSE than estimations based on the hygroscopic water reported by Arthur et al. (2015). However, for soils first classified as clays with finger assessment, the regression model based on ST data can be used to get more precise information on the clay content of the soil.

\section{Conclusions}

In the present study, pedotransfer functions were developed for predicting the soil clay content, potential CEC and TA. The estimation of potential CEC was based on 148 mineral and 67 organic soil samples collected from plough layers from various parts of Finland, which were further grouped into different soil types. In the studied soils, the means of potential CEC and TA increased from coarse-textured soils to heavy clay soils and mull soils to peat soils. The results highlighted the importance of TA as a prominent or predominant component of the potential CEC. The results of Finnish soil test (acid ammonium acetate-extraction, $\mathrm{pH} 4.65$ ) can be used in estimating the potential CEC as STCat and pH explain $83 \%$ of the variation and together with SOC $96 \%$ of the variation. In estimating TA, knowledge of SOC is required and SOC and pH explained $86 \%$ of the variation. Soil test data can also be utilized in estimating the clay content especially for soils with clay content over $30 \%$. However, SOC hampers STCat based estimations on clay content especially in coarse-textured soils.

\section{Acknowledgements}

This study was funded by Marjatta ja Eino Kollin Säätiö. The authors thank the staff at Luke Jokioinen laboratory for supplementary chemical analysis.

\section{References}

Aaltonen, V.T., Aarnio, B., Hyyppä, E., Kaitera, P., Keso, L., Kivinen, E., Kokkonen, P., Kotilainen, M.J., Sauramo, M., Tuorila, P. \& Vuorinen, J. 1949. Maaperäsanaston ja maalajien luokituksen tarkistus v. 1949. Summary; critical review of soil terminology and soil classification in Finland in the year 1949. Journal of the Scientific Agricultural Society of Finland 21: 37-66. https://doi.org/10.23986/afsci.71269

Aksoy, E., Yigini, Y. \& Montanarella, L. 2016. Combining soil databases for topsoil organic carbon mapping in Europe. PLoS ONE 11: e0152098. https://doi.org/10.1371/journal.pone.0152098

Arthur, E., Tuller, M., Moldrup, P., Jensen, D.K. \& De Jonge, L.W. 2015. Prediction of clay content from water vapour sorption isotherms considering hysteresis and soil organic matter content. European Journal of Soil Science 66: 206-217. https://doi.org/10.1111/ejss.12191

Bache, B.W. 1976. The measurement of cation exchange capacity of soils. Journal of the Science of Food and Agriculture 27: 273-280. https://doi.org/10.1002/jsfa.2740270313

Bell, M.A. \& van Keulen, H. 1995. Soil pedotransfer functions for four Mexican soils. Soil Science Society of America Journal 59: 865-871. https://doi.org/10.2136/sssaj1995.03615995005900030034x

Bohn, H.L., McNeal, B.L. \& O’Connor, G.A. 2001. Soil Chemistry. 2nd ed. New York, USA: John Wiley \& Sons, Inc. 307 p.

Cabrera, F. \& Talibudeen, O. 1977. Effect of soil pH and organic matter on labile aluminium in soils under permanent grass. European Journal of Soil Science 28: 259-270. http://dx.doi.org/10.1111/j.1365-2389.1977.tb02234.x

Ciesielski, H., Sterckeman, T., Santerne, M. \& Willery, J.P. 1997. A comparison between three methods for the determination of cation exchange capacity and exchangeable cations in soils. Agronomie 17: 9-16. https://doi.org/10.1051/agro:19970102

Coscione, A.R., de Andrade, J.C. \& van Raij, B. 1998. Revisiting titration procedures for the determination of exchangeable acidity and exchangeable aluminum in soils. Communications in Soil Science and Plant Analysis 29: 1973-1982. https://doi.org/10.1080/00103629809370086

Curtin, D., Campbell, C.A. \& Messer, D. 1996. Prediction of titratable acidity and soil sensitivity to pH change. Journal of Environmental Quality 25: 1280-1284. https://doi.org/10.2134/jeq1996.00472425002500060016x

Dai, K.H. \& Richter, D.D. 2000. A re-examination of exchangeable acidity as extracted by potassium chloride and potassium fluoride. Communications in Soil Science and Plant Analysis 31: 115-139. https://doi.org/10.1080/00103620009370424

Elonen, P. 1971. Particle-size analysis of soil. Acta Agralia Fennica 122: 1-122. 
Fooladmand, H.R. 2008. Estimating cation exchange capacity using soil textural data and soil organic matter content: A case study for the south of Iran. Archives of Agronomy and Soil Science 54: 381-386. https://doi.org/10.1080/03650340802158193

Graham, E.R. 1959. An explanation of theory and methods of soil testing. Bulletin 734. Columbia, USA: University of Missouri, Agricultural Experiment Station. 20 p.

Halonen, R. \& Juusela, T. 1957. Suomen peltojen maalajit, muokkauskerroksen syvyys ja maan happamuus. The Journal of the Scientific Agricultural Society of Finland. 29: 150-166. (in Finnish, summary in English) https://doi.org/10.23986/afsci.71420

Hassink, J. 1996. Preservation of plant residues in soils differing in unsaturated protective capacity. Soil Science Society of America Journal 60: 487-491.https://doi.org/10.2136/sssaj1996.03615995006000020021x

Heikkinen, J., Keskinen, R., Regina, K., Honkanen, H. \& Nuutinen, V. 2021. Estimation of carbon stocks in boreal cropland soils methodological considerations. European Journal of Soil Science: 72:934-945. https://doi.org/10.1111/ejss.13033

Hyväluoma, J., Räty, M., Kaseva, J. \& Keskinen, R. 2020. Changes over time in near-saturated hydraulic conductivity of peat soil following reclamation for agriculture. Hydrological Processes 34: 237-243. https://doi.org/10.1002/hyp.13578

IUSS Working Group WRB 2015. World Reference Base for Soil Resources 2014, update 2015. International soil classification system for naming soils and creating legends for soil maps. World Soil Resources Reports No. 106. FAO, Rome. 192 p.

Kahr, G. \& Madsen, F.T. 1995. Determination of the cation exchange capacity and the surface area of bentonite, illite and kaolinite by methylene blue adsorption. Applied Clay Science 9: 327-336. https://doi.org/10.1016/0169-1317(94)00028-O

Kaila, A. 1971a. Effective cation-exchange capacity in Finnish mineral soils. The Journal of the Scientific Agricultural Society of Finland 43: 178-186. https://doi.org/10.23986/afsci.71796

Kaila, A. 1971b. Aluminium and acidity in Finnish soils. The Journal of the Scientific Agricultural Society of Finland 43: 11-19. https://doi.org/10.23986/afsci.71779

Kaila, A. 1972. Basic exchangeable cations in Finnish mineral soils. The Journal of the Scientific Agricultural Society of Finland 44: 164-170. https://doi.org/10.23986/afsci.71821

Keskinen, R., Ketoja, E., Heikkinen, J., Salo, T., Uusitalo, R. \& Nuutinen, V. 2016. 35-year trends of acidity and soluble nutrients in cultivated soils of Finland. Geoderma Regional 7: 376-387. https://doi.org/10.1016/j.geodrs.2016.11.005

Krogh, L., Breuning-Madsen, H. \& Greve, M.H. 2000. Cation-exchange capacity pedotransfer functions for Danish soils. Acta Agriculturae Scandinavica, Section B - Plant Soil Science 50: 1-12. https://doi.org/10.1080/090647100750014358

Lemola, R., Uusitalo, R., Hyväluoma, J., Sarvi, M. \& Turtola, E. 2018. Suomen peltojen maalajit, multavuus ja fosforipitoisuus. Vuodet 1996-2000 ja 2005-2009. Luonnonvara- ja biotalouden tutkimus 17/2018. 209 p. (in Finnish, summary in English)

Luke 2020. Economydoctor. Soil class information service. Data: Luke Soil class data. Surface soil types, national classification. https://portal.mtt.fi/portal/page/portal/economydoctor/soil_class_information/timeline/surface_soil types_national_classification/region. Accessed 23 September 2020

Manrique, L.A., Jones, C.A. \& Dyke, P.T. 1991. Predicting cation-exchange capacity from soil physical and chemical properties. Soil Science Society of America Journal 55: 787-794. https://doi.org/10.2136/sssaj1991.03615995005500030026x

Martel, Y.A., De Kimpe, C.R. \& Laverdière, M.R. 1978. Cation-exchange capacity of clay-rich soils in relation to organic matter, mineral composition, and surface area. Soil Science Society of America Journal 42: 764-767.

https://doi.org/10.2136/sssaj1978.03615995004200050023x

Marttila, U. 1965. Exchangeable cations in Finnish soils. The Journal of the Scientific Agricultural Society of Finland 37: 148-161. https://doi.org/10.23986/afsci.71634

Mattila, T.J. \& Rajala, J. 2020. OSMO soil health dataset 2015-2018 [Data set]. Zenodo. https://doi.org/10.5281/zenodo.3589102 Accessed 9 August 2021

McBratney, A.B., Minasny, B., Cattle, S.R. \& Vervoort, R.W. 2002. From pedotransfer functions to soil inference systems. Geoderma 109: 41-73. https://doi.org/10.1016/S0016-7061(02)00139-8

Mishra, G., Das, J. \& Sulieman, M. 2019. Modelling soil cation exchange capacity in different land-use systems using artificial neural networks and multiple regression analysis. Current Science 116: 2020-2027. https://doi.org/10.18520/cs/v116/i12/2020-2027

Mäkitie, O. \& Virri, K. 1965. On the exchange characteristics of some clay soils in the middle Uusimaa. Annales Agriculturae Fenniae 4: 277-289.

Nelson, D.W. \& Sommers, L.E. 1996. Total carbon, organic carbon and organic matter. In: Sparks, D.L., Page, A.L., Helmke, P.A., Loeppert, R.H., Soltanpour, P.N., Tabatabai, M.A., Johnston, C.T. \& Sumner, M.E. (eds.). Methods of Soil Analysis: Part 3 Chemical Methods, 5.3. Number 5 in the Soil Science Society of America Book Series. Madison, Wisconsin, USA: Soil Science Society of America, Inc., American Society of Agronomy, Inc. p. 961-1010.

Niskanen, R. \& Jaakkola, A. 1986. Estimation of cation-exchange capacity in routine soil testing. Journal of Agricultural Science in Finland 58: 1-7. https://doi.org/10.23986/afsci.72214

Paasonen-Kivekäs, M. \& Yli-Halla, M. 2005. A comparison of nitrogen and carbon reserves in acid sulphate and non acid sulphate soils in western Finland. Agricultural and Food Science 14: 57-69. https://doi.org/10.2137/1459606054224174

Palojärvi, A., Alakukku, L., Martikainen, E., Niemi, M., Vanhala, P., Jorgensen, K. \& Esala, M. 2002. Effects of organic and conventional farming on soil. Maa- ja elintarviketalous 2. 88 p. (in Finnish, summary in English)

Parfitt, R.L., Giltrap, D.J. \& Whitton, J.S. 1995. Contribution of organic matter and clay minerals to the cation exchange capacity of soils. Communications in Soil Science and Plant Analysis 26: 1343-1355. https://doi.org/10.1080/00103629509369376

Peltovuori, T., Uusitalo, R. \& Kauppila, T. 2002. Phosphorus reserves and apparent phosphorus saturation in four weakly developed cultivated pedons. Geoderma 110: 35-47. https://doi.org/10.1016/S0016-7061(02)00180-5 
Reuter, H.I., Lado, L.R., Hengl, T. \& Montanarella, L. 2008. Continental-scale digital soil mapping using european soil profile data: soil pH. Hamburger Beiträge zur Physischen Geographie und Landschaftsökologie - 92 Heft 19/2008. p. 91-102. https://esdac.jrc. ec.europa.eu/public_path/shared_folder/dataset/10_soil_ph/soil_ph_in_europe_hbpl19_10.pdf. Accessed 23 September 2020.

Ross, D.S. \& Ketterings, Q. 1995. Recommended methods for determining soil cation exchange capacity. Cooperative Bulletin No. 493: 75-86.

Seybold, C.A., Grossman, R.B. \& Reinsch, T.G. 2005. Predicting cation exchange capacity for soil survey using linear models. Soil Science Society of America Journal 69: 856-863. https://doi.org/10.2136/sssaj2004.0026

Sillanpää, M. 1982. Micronutrients and the Nutrient Status of Soils: A Global Study. FAO Soils Bulletin No. 48. Food and Agriculture Organization of the United Nations, Rome, Italy. 458 p.

Sippola, J. 1974. Mineral composition and its relation to texture and to some chemical properties in Finnish subsoils. Annales Agriculturae Fenniae 13: 169-234.

Soinne, H., Hyväluoma, J., Ketoja, E. \& Turtola, E. 2016. Relative importance of organic carbon, land use and moisture conditions for the aggregate stability of post-glacial clay soils. Soil and Tillage Research 158: 1-9. https://doi.org/10.1016/j.still.2015.10.014

Soinne, H., Keskinen, R., Räty, M., Kanerva, S., Turtola, E., Kaseva, J., Nuutinen, V., Simojoki, A. \& Salo, T. 2021. Soil organic carbon and clay content as deciding factors for net nitrogen mineralization and cereal yields in boreal mineral soils. European Journal of Soil Science 72: 1497-1512. https://doi.org/10.1111/ejss.13003

Sulieman, M., Saeed, I., Hassaballa, A. \& Rodrigo-Comino, J. 2018. Modeling cation exchange capacity in multi geochronological-derived alluvium soils: An approach based on soil depth intervals. Catena 167: 327-339. https://doi.org/10.1016/j.catena.2018.05.001

Sumner, M.E. \& Miller, W.P. 1996. Cation exchange capacity and exchange coefficients. In: Sparks, D.L., Page, A.L., Helmke, P.A. Loeppert, R.H., Soltanpour, P.N., Tabatabai, M.A., Johnston, C.T. \& Sumner, M.E. (eds.). Methods of Soil Analysis: Part 3 Chemical Methods, 5.3. Number 5 in the Soil Science Society of America Book Series. Madison, Wisconsin, USA: Soil Science Society of America, Inc., American Society of Agronomy, Inc. p. 1201-1229.

Syers, J.K., Campbell, A.S. \& Walker, T.W. 1970. Contribution of organic carbon and clay to cation exchange capacity in a chronosequence of sandy soils. Plant and Soil 33: 104-112. https://doi.org/10.1007/BF01378202

Thompson, M.L., Zhang, H., Kazemi, M. \& Sandor, J.A. 1989. Contribution of organic matter to cation exchange capacity and specific surface area of fractionated soil materials. Soil Science 148: 250-257. https://doi.org/10.1097/00010694-198910000-00003

Vuorinen, J. \& Mäkitie, O. 1955. The method of soil testing in use in Finland. Agrogeological Publications No 63. 44 p.

Wesselink, L.G., van Breemen, N., Mulder, J. \& Janssen, P.H. 1996. A simple model of soil organic matter complexation to predict the solubility of aluminium in acid forest soils. European Journal of Soil Science 47: 373-384. https://doi.org/10.1111/j.1365-2389.1996.tb01411.x

White, R.E. 1997. Principles and Practice of Soil Science. The Soil as a Natural Resource. 3rd ed. Oxford, UK: Blackwell Science Ltd. $348 \mathrm{p}$.

Wiesmeier, M., Urbanski, L., Hobley, E., Lang, B., von Lützow, M., Marin-Spiotta, E., van Wesemael, B., Rabot, E., Ließ, M., GarciaFranco, N., Wollschläger, U., Vogel, H.-J. \& Kögel-Knabner, I. 2019. Soil organic carbon storage as a key function of soils - A review of drivers and indicators at various scales. Geoderma 333: 149-162. https://doi.org/10.1016/j.geoderma.2018.07.026

Yli-Halla, M. \& Mokma, D.L. 1998. Soil temperature regimes in Finland. Agricultural and Food Science in Finland 7: 507-512. https://doi.org/10.23986/afsci.5606

Yli-Halla, M. \& Mokma, D.L. 2001. Soils in an agricultural landscape of Jokioinen, south-western Finland. Agricultural and Food Science in Finland 10: 33-43. https://doi.org/10.23986/afsci.5677

Yli-Halla, M., Mokma, D.L., Peltovuori, T. \& Sippola, J. 2000. Suomalaisia maaprofiileja. Agricultural soil profiles and their classification. Maatalouden tutkimuskeskuksen julkaisuja. Sarja A 78. Maatalouden tutkimuskeskus, Jokioinen, Finland. 104 p. (in Finnish, summary in English)

Yli-Halla, M. \& Nyborg, Å. 2013. Suomen kivennäismaapeltojen maannokset WRB-järjestelmän mukaan. In: Leppälammi-Kujansuu, J., Merilä, P., Rankinen, K., Salo, T., Soinne, H. \& Hänninen, P. (eds.). VII Maaperätieteiden päivien abstraktit. Pro Terra No. 61. Helsinki: Suomen Maaperätieteiden Seura, Helsingin yliopisto, Elintarvike- ja ympäristötieteiden laitos. p. 25-26. (in Finnish)

Yli-Halla, M. \& Peltovuori, T. 2009. Maannokset ja niiden luokittelu. In: Paasonen-Kivekäs, M., Peltomaa, R., Vakkilainen, P. \& Äijö, H. (eds.). Maan vesi- ja ravinnetalous. Ojitus, kastelu ja ympäristö. Helsinki, Finland: Salaojayhdistys ry. p. 39-46. (in Finnish) 